\title{
In situ observations of microstructural changes in SOFC anodes during redox cycling
}

\author{
Klemensø, Trine; Appel, C. C.; Mogensen, Mogens Bjerg
}

Published in:

Electrochemical and Solid-State Letters

Link to article, DOI:

$10.1149 / 1.2214303$

Publication date:

2006

Document Version

Publisher's PDF, also known as Version of record

Link back to DTU Orbit

Citation (APA):

Klemensø, T., Appel, C. C., \& Mogensen, M. B. (2006). In situ observations of microstructural changes in SOFC anodes during redox cycling. Electrochemical and Solid-State Letters, 9(9), A403-A407.

https://doi.org/10.1149/1.2214303

\section{General rights}

Copyright and moral rights for the publications made accessible in the public portal are retained by the authors and/or other copyright owners and it is a condition of accessing publications that users recognise and abide by the legal requirements associated with these rights.

- Users may download and print one copy of any publication from the public portal for the purpose of private study or research.

- You may not further distribute the material or use it for any profit-making activity or commercial gain

- You may freely distribute the URL identifying the publication in the public portal

If you believe that this document breaches copyright please contact us providing details, and we will remove access to the work immediately and investigate your claim 


\title{
In Situ Observations of Microstructural Changes in SOFC Anodes during Redox Cycling
}

\author{
T. Klemensø, ${ }^{\text {a,b,c,z }}$ C. C. Appel, ${ }^{\text {d }}$ and M. Mogensen ${ }^{\mathrm{a}, *}$ \\ ${ }^{a}$ Fuel Cells and Solid State Chemistry Department, Ris $\phi$ National Laboratory, 4000 Roskilde, Denmark \\ ${ }^{b}$ Department of Chemistry, Technical University of Denmark, 2800 Kgs. Lyngby, Denmark \\ ${ }^{c}$ Topsoe Fuel Cell A/S, 2800 Kgs. Lyngby, Denmark \\ ${ }^{d}$ Haldor Topsфe A/S, 2800 Kgs. Lyngby, Denmark
}

The anode-supported solid oxide fuel cell (SOFC) degrades when the anode is subjected to redox cycling. The degradation has qualitatively been related to microstructural changes in the nickel-yttria stabilized zirconia anode of the tested cells. In this work, the microstructural changes were observed in situ using environmental scanning electron microscopy. In the reduced state, a dynamic rounding of the nickel particles occurred. The oxide growth upon re-oxidation depended on the oxidation kinetics. During rapid oxidation, the $\mathrm{NiO}$ particles divided into 2-4 particles, which grew into the surrounding voids. For slower oxidation, an external oxide layer was seen to develop around the individual particles. (C) 2006 The Electrochemical Society. [DOI: 10.1149/1.2214303] All rights reserved.

Manuscript submitted February 24, 2006; revised manuscript received May 10, 2006. Available electronically June $22,2006$.

The performance of the nickel-yttria stabilized zirconia (YSZ) anode is known to degrade during operation, ${ }^{1-4}$ and when subjected to redox cycling. ${ }^{5-8}$ The degradation has been attributed to changes on the microstructural level. ${ }^{9}$

Conventional light microscopy and scanning electron microscopy (SEM) are restricted to microstructure studies of tested samples. For detectable changes to occur, the investigations are limited to redox cycled samples or samples tested for thousands of hours. The observations are further restricted by difficulties in distinguishing the phases. With light microscopy, the high reflectivity of the Ni phase prevents differentiation of pores and YSZ. With SEM, the similar backscattering coefficients of $\mathrm{Ni}$ and YSZ result in low image contrast, allowing only the pores to be distinguished from the solid phases.

Previous studies by other researchers have been limited to individual phases, ${ }^{1,10-12}$ or involved specific treatments of the samples, ${ }^{1,13,14}$ or the images. ${ }^{15}$ The investigations displayed coarsening and rounding of the nickel particles upon exposure to reducing conditions. ${ }^{1,12}$ Oxidation was seen to be associated with increased porosity, ${ }^{16-18}$ cracks,${ }^{5,7}$ swelling of the $\mathrm{NiO}$ particles, ${ }^{19}$ or qualitatively finer $\mathrm{NiO}$ grains. ${ }^{5}$

In this work, the microstructural changes during reduction and re-oxidation was observed in situ using environmental scanning electron microscopy (ESEM). The experiment was performed on a nickel-3YSZ (3 mol \% YSZ) cermet, which is a relevant material for the SOFC anode. With this technique, it was possible to follow the individual nickel-containing particles upon the redox treatment.

\section{Experimental}

Sample preparation.- Samples were prepared from NiO powder (99\% from Alfa Aesar), alumina powder (Catapal from Sasol), and $3 \mathrm{~mol} \%$ YSZ (3YSZ) (TZ-3YB from Tosoh Co.). The solid material content was 55.7 wt \% NiO, 43.7 wt \% 3YSZ, 0.6 wt \% $\mathrm{Al}_{2} \mathrm{O}_{3}$. The powders were processed into a slurry. The slurry was tape cast into a thin foil and the green foil was heat treated at $600^{\circ} \mathrm{C}$ to burn out the organics. The resulting powder was pressed into bar shaped samples. Uniaxial pressing followed by isostatic pressing at $80 \mathrm{MPa}$ was carried out. The bars were subsequently sintered at $1300^{\circ} \mathrm{C}$

A portion of each set of bars was reduced for either 1 or $96 \mathrm{~h}$ in 9 vol $\% \mathrm{H}_{2}-\mathrm{N}_{2}$ at $1000^{\circ} \mathrm{C}$. A portion of these were subsequently re-oxidized in air for $1 \mathrm{~h}$. The complete reduction and re-oxidation of the bars were verified by changes in weight and XRD.

For the ESEM experiment, an as-sintered sample piece was used.

* Electrochemical Society Active Member

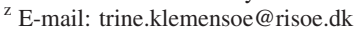

One side of the sample was polished using diamond paste. Polishing was continuously checked in the optical microscope. Neither pullout of grains nor smearing was observed to occur during polishing. The polished sample was cleaned in ethanol in an ultrasonic bath The sample was fractured and positioned in the sample holder in a way that allowed both the polished and fractured surfaces to be observed.

The samples were also examined with a Leitz Aristomet optical microscope, and a SEM of the type FEI Quanta 600 equipped with EDAX thin window detector and EDAX Genesis software. These samples were cast into epoxy resin, and polished. Particle pull-out or $\mathrm{Ni}$ smearing was not observed during polishing. A silver coating of $10 \mathrm{~nm}$ was subsequently applied to minimize charging effects. The images of the microstructures were analyzed with the image analysis software Image Pro-Plus 4.0 (Media Cybernetics).

X-ray powder diffraction (XRD) was used for identification of the phases present. A Stoe Bragg-Brentano diffractometer with $\mathrm{Cu} \mathrm{K} \alpha \mathrm{X}$-ray as radiation source was used.

Light scattering particle sizing (also known as laser diffraction) was used for analysis of the particle size distribution. A Beckman Coulter LS 13320 instrument, with a measurement range of 0.04-2000 $\mu \mathrm{m}$ was applied.

Experimental procedure for the ESEM experiment.- The assintered sample was fixed in a gas flow heating stage, which can be operated between 20 and $1000^{\circ} \mathrm{C}$, and mounted into the ESEM (Philips XL30 ESEM-FEG). The sample was fixed in a hollow graphite crucible, placed in the heating stage. Reducing or oxidizing gas was introduced via an inlet at the bottom of the heating stage and passed through the crucible and across the specimen. A cap with

Table I. Program for redox cycling of an as-sintered sample in the ESEM.

\begin{tabular}{|c|c|c|c|c|c|c|}
\hline Process & Step & $\begin{array}{l}T_{\text {start }} \\
\left({ }^{\circ} \mathrm{C}\right)\end{array}$ & $\begin{array}{l}T_{\text {end }} \\
\left({ }^{\circ} \mathrm{C}\right)\end{array}$ & $\begin{array}{c}\text { Average } \\
\text { ramp } \\
\left({ }^{\circ} \mathrm{C} / \mathrm{min}\right)\end{array}$ & $\begin{array}{c}\text { Dwell } \\
\text { time } \\
(\mathrm{min})\end{array}$ & Atmosphere \\
\hline \multirow[t]{2}{*}{ 1st Reduction } & Heating & 20 & 850 & 9 & - & $9 \% \mathrm{H}_{2}-\mathrm{Ar}$ \\
\hline & Hold & 850 & 850 & - & 44 & $9 \% \mathrm{H}_{2}-\mathrm{Ar}$ \\
\hline \multirow[t]{3}{*}{ 1st Re-oxidation } & Purging & 850 & 850 & - & 2 & $\mathrm{~N}_{2}$ \\
\hline & Hold & 850 & 850 & - & 65 & Air \\
\hline & Cooling & 850 & 20 & 25 & - & Air \\
\hline \multirow[t]{3}{*}{ 2nd Reduction } & Heating & 20 & 850 & 9 & - & $9 \% \mathrm{H}_{2}-\mathrm{Ar}$ \\
\hline & Hold & 850 & 850 & - & 141 & $9 \% \mathrm{H}_{2}-\mathrm{Ar}$ \\
\hline & Cooling & 850 & 20 & 25 & - & $9 \% \mathrm{H}_{2}-\mathrm{Ar}$ \\
\hline \multirow[t]{3}{*}{ 2nd Re-oxidation } & Heating & 20 & 850 & 9 & - & Air \\
\hline & Hold & 850 & 850 & - & 86 & Air \\
\hline & Cooling & 850 & 20 & 25 & - & Air \\
\hline
\end{tabular}



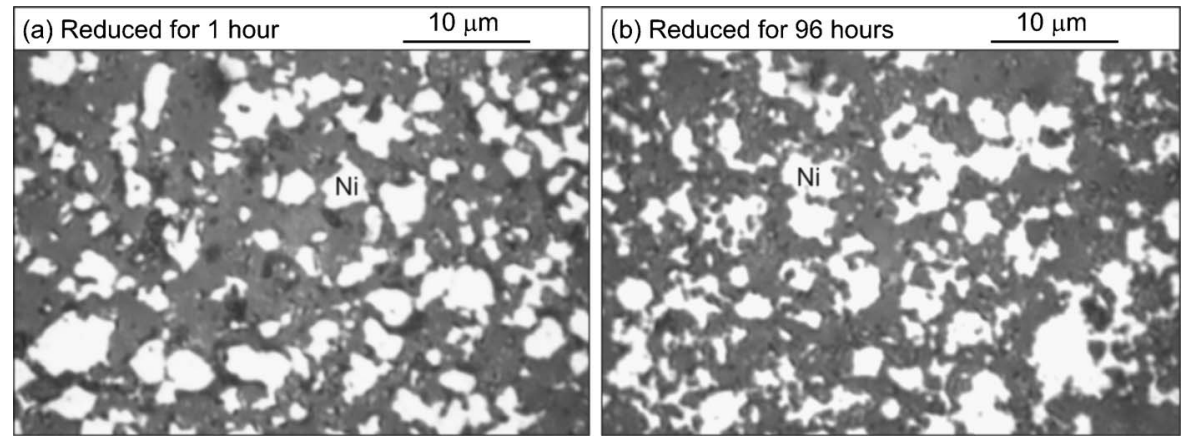

Figure 1. Light microscopy micrographs of samples reduced for 1 (a) and $96 \mathrm{~h} \mathrm{(b)}$.

a small aperture ( $2 \mathrm{~mm}$ diam) was placed above the sample to keep the concentration of reaction gas around the sample as high as possible. The specimen chamber above the cap was filled with $\mathrm{N}_{2}$ during the experiments. The imaging was done with a GSE (gaseous secondary electron) detector. Redox cycling was carried out at temperatures up to $850^{\circ} \mathrm{C}$, with total gas pressures around 5-10 mbar. Reductions were done in 9 vol $\% \mathrm{H}_{2}-\mathrm{Ar}$ (nominally dry, $\mathrm{pO}_{2}$ probably lower than $10^{-17}$ mbar) and oxidations in air.

Three temperature cycles and two redox cycles were performed, using the program given in Table I. First, the as-sintered sample was heated in 9 vol $\% \mathrm{H}_{2}-\mathrm{Ar}$ up to $850^{\circ} \mathrm{C}$ using an average ramp rate of $9^{\circ} \mathrm{C} / \mathrm{min}$, allowing reduction to occur during heating. Heating was not done with a constant ramp rate, because the temperature was kept constant while micrographs were obtained. When the temperature of $850^{\circ} \mathrm{C}$ was attained, the reducing atmosphere was maintained for $44 \mathrm{~min}$. The chamber was then briefly purged with $\mathrm{N}_{2}$ for $2 \mathrm{~min}$ and then air was introduced (first re-oxidation, cf. Table I). After 65 min with air, the sample was cooled down in air to room temperature at an average cooling ramp of $\sim 25^{\circ} \mathrm{C} / \mathrm{min}$.

The sample was again heated while being exposed to the reducing atmosphere (second reduction, cf. Table I). After the end temperature was attained, the conditions were maintained for $141 \mathrm{~min}$ before cooling the sample in the reducing atmosphere.
Finally, the sample was heated in air (second re-oxidation, cf. Table I). Thus, the second re-oxidation took place while heating slowly to $850^{\circ} \mathrm{C}$. When the temperature was achieved, the conditions were kept for $86 \mathrm{~min}$ before cooling the sample in the oxidizing atmosphere.

With ESEM, chemical analyses were not possible. As such, only microstructural observations were made. Verification of the complete reduction or re-oxidation during the redox steps could therefore not be done.

\section{Results}

Phases.-XRD analysis of as-sintered samples was performed on the surface of solid specimens since crushing was observed to affect the zirconia phase. The phases present were determined to be $\mathrm{NiO}$ and tetragonal zirconia partially stabilized by yttria (t-YSZ). The tetragonal parameters were determined by Werner lattice refinement to $c=5.1704 \pm 0.0007 \AA$, and $a=b=3.6084 \pm 0.0004 \AA$. This was in agreement with the lattice parameters reported for the tetragonal composition $\mathrm{Zr}_{68.8} \mathrm{Y}_{5.8} \mathrm{O}_{25.6}$, where $c=5.1675 \AA$ and $a$ $=3.6110 \AA$ (JCDPS-card 48-0224).

For reduced or re-oxidized samples, the XRD analyses were
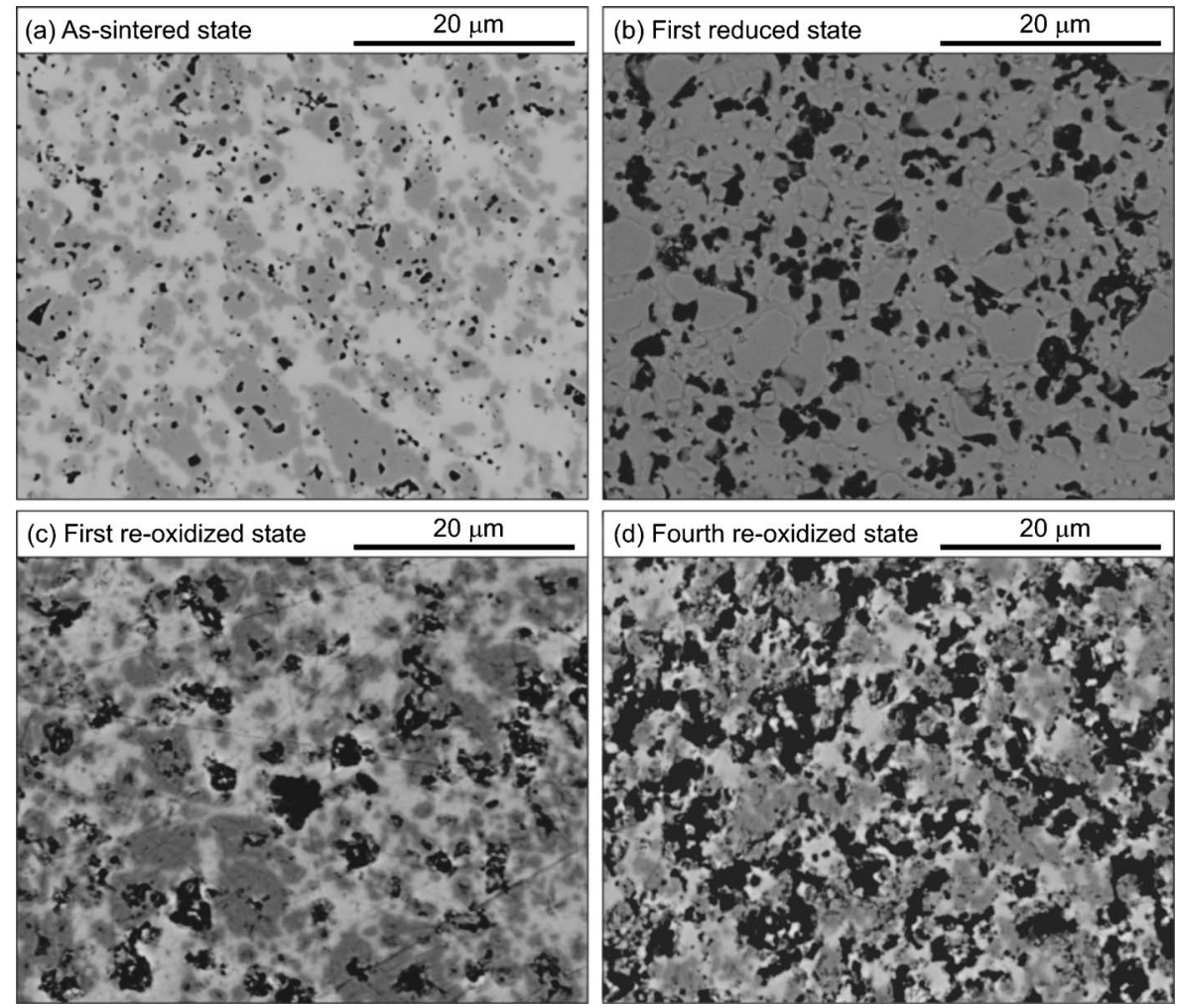

Figure 2. SEM-BSE micrographs. (a) Assintered state, (b) first reduced state, (c) first re-oxidized state and (d) fourth reoxidized state. 

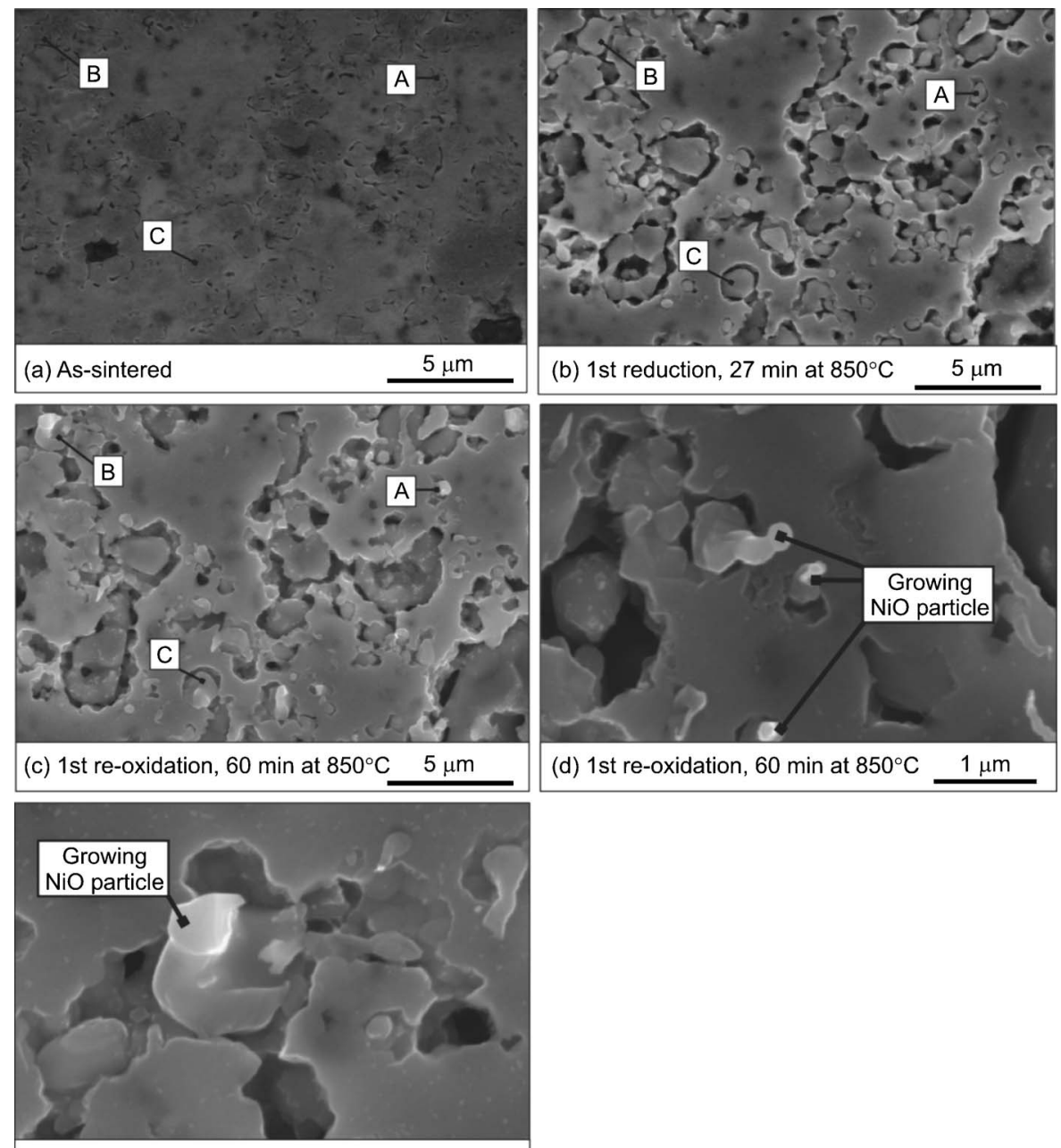

(e) 1 st re-oxidation, $60 \mathrm{~min}$ at $850^{\circ} \mathrm{C}$

$1 \mu \mathrm{m}$

done after crushing the samples. Complete reduction and reoxidation was indicated by the presence of solely $\mathrm{Ni}$ or $\mathrm{NiO}$, respectively.

Particle size distribution. - The particle size distribution of the slurry for tape casting and the powder for pressing was analyzed by light scattering particle sizing. It was possible to analyze the mixture of $\mathrm{NiO}$ and t-YSZ particles, as the refractive index of the two phases is similar. The refractive index for $\mathrm{NiO}$ is 2.1818 , and for $\mathrm{ZrO}_{2}$ it is within the range $2.19-2.20 .^{20}$

Similar particle size distributions for the slurry and the powder were observed. In both cases, it was approximately unimodal, with a $50 \%$ quantile $\left(\mathrm{D}_{50}\right)$ around $2 \mu \mathrm{m}$. The $50 \%$ quantile is defined as the maximum diameter of $50 \mathrm{vol} \%$ of the particles. The uncertainty of the instrument was estimated to be $0.3 \mu \mathrm{m}$ on the $50 \%$ quantile.

Light microscopy. - Representative micrographs obtained with light microscopy of samples reduced for, respectively, 1 and $96 \mathrm{~h}$ are shown in Fig. 1. The metallic nickel is clearly distinguished as the brighter phase. No qualitative or quantitative differences were observed upon ageing. Between 1435 to $2530 \mathrm{Ni}$ grains were identified and analyzed using image analysis. No significant changes in average grain diameter, grain area, or roundness were observed.

SEM.- Representative micrographs from the SEM of samples in the as-sintered, reduced, and re-oxidized states are shown in Fig. 2. Backscattered electrons (BSE) were used for the imaging. The three phases were distinguishable in the oxidized state. The brighter phase is t-YSZ, NiO is the darker phase, and the pores appear black. In the reduced state it was only possible to distinguish between pores (black) and solid phase (bright) since the backscattering coefficients of t-YSZ and Ni are similar.

From Fig. 2, changes in the microstructure upon reduction and re-oxidation were evident. Compared to the as-sintered state, both the reduced and the re-oxidized states appeared more porous. Figures $2 \mathrm{c}$ and $\mathrm{d}$ illustrate the structure after, respectively, the first and fourth re-oxidation. Upon successive oxidation, the structure became increasingly porous and the pores appeared coarser and more coherent. In contrast, the solid phase, especially the YSZ network, became less coherent with the number of oxidations. Distinct microcracking was not observed (cf. Fig. 2c and d); however the reoxidations were associated with macroscopic fracture. Upon the first re-oxidation, $10 \%$ of the samples displayed macro cracks. Upon subsequent cycling, the cracks became increasingly frequent and more severe.

Heating in the ESEM.- Individual particles were followed in situ upon redox cycling. During redox cycling, the nickel grains changed in size and shape and were distinguishable from the t-YSZ grains, which appeared unaffected. The composition of the phases was further verified with SEM/energy dispersive X-ray (EDX) spectrometry.

Figure 3 illustrates a fixed sample area upon the first redox steps. Three nickel particles were selected for observation, indicated by the letters A, B, and C (cf. Fig. 3a-c). In the as-sintered state, the individual nickel grains were difficult to discern (cf. Fig. 3a). When the first reduction was started, the outline of the grains appeared within minutes as the nickel particles shrunk in size. The nickel grains 


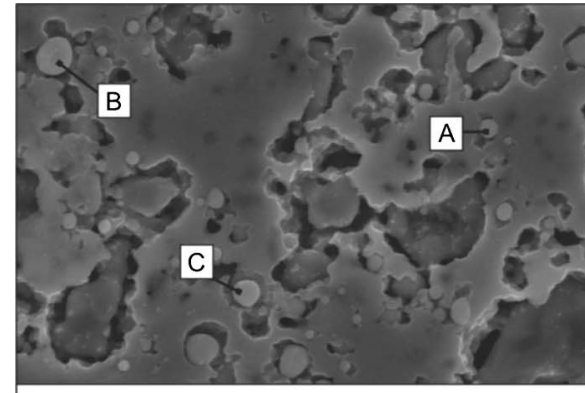

(a) $2 \mathrm{nd}$ reduction, $120 \mathrm{~min}$ at $850^{\circ} \mathrm{C} \quad 5 \mu \mathrm{m}$

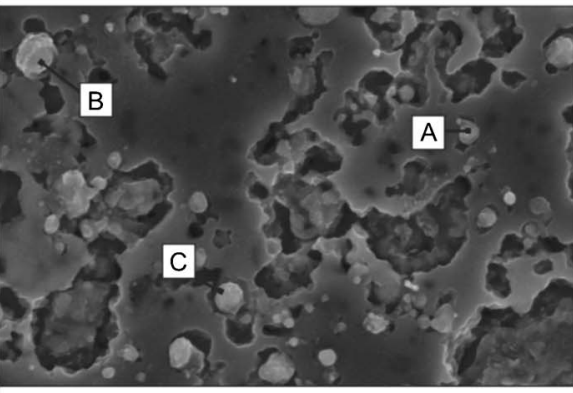

(c) 2nd re-oxidation, $80 \mathrm{~min}$ at $850^{\circ} \mathrm{C} \quad 5 \mu \mathrm{m}$

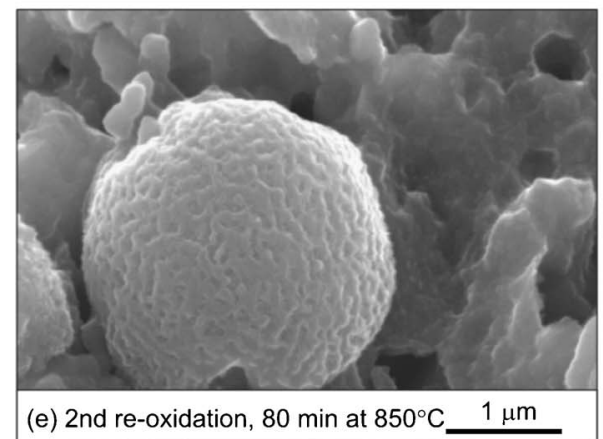

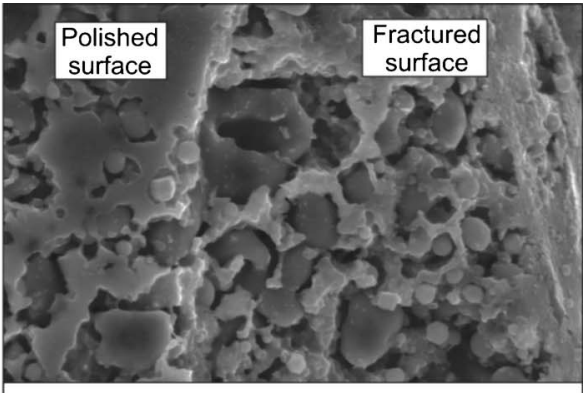

(b) $2 \mathrm{nd}$ reduction, $120 \mathrm{~min}$ at $850^{\circ} \mathrm{C} \quad 5 \mu \mathrm{m}$

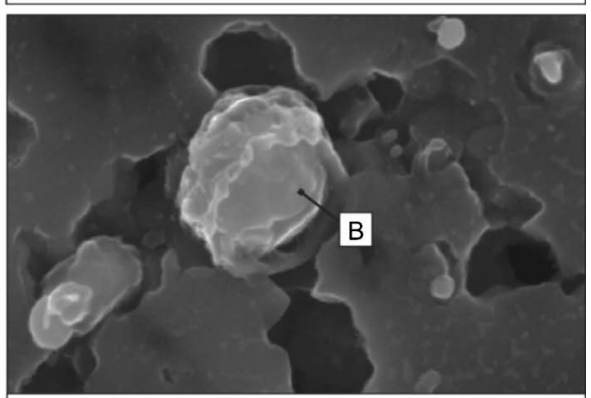

(d) $2 \mathrm{nd}$ re-oxidation, $80 \mathrm{~min}$ at $850^{\circ} \mathrm{C} \quad 1 \mu \mathrm{m}$
Figure 4. ESEMs from the second redox cycle. Images (a) and (c) show the same area as Fig. 4a-c, and the three Ni particles $\mathrm{A}, \mathrm{B}$, and $\mathrm{C}$ are indicated. (a) Reducing conditions, $120 \mathrm{~min}$ at $850^{\circ} \mathrm{C}$, (b) polished and fractured surface after $120 \mathrm{~min}$ at $850^{\circ} \mathrm{C}$ and reducing conditions, (c) reoxidizing conditions, $80 \mathrm{~min}$ at $850^{\circ} \mathrm{C}$ and ( $\mathrm{d}$ and $\mathrm{e}$ ) close-up of growing nickel particles after $80 \mathrm{~min}$ of re-oxidizing conditions at $850^{\circ} \mathrm{C}$. decreased further in size and became increasingly rounded as the reduction proceeded. The rounding was observed to be faster for smaller grains than for larger grains (cf. Fig. 3b).

When re-oxidized for the first time at $850^{\circ} \mathrm{C}$, the nickel particles increased in size but did not revert to the as-sintered shape (cf. Fig. $3 c$ ). Instead, the particles were observed to separate into 2-4 grains and to grow out of the polished plane. Higher magnification micrographs of some of the growing structures are shown in Fig. 3d and e. The out-of-plane growth was observed as the brighter parts of the particles.

Figure 4 displays micrographs from the same sample area after the second redox step. Upon re-reduction (second reduction), the fragmented oxidized nickel particles coalesced into single particles with a smaller cross-section compared to that observed after the first oxidation step (see Fig. 3c and 4a). After exposure to reducing conditions for $120 \mathrm{~min}$, the nickel grains appeared more spherical than the nickel grains observed after the first reduction. The rounded shape was particularly evident at fracture surfaces (cf. Fig. 4b).

In contrast to the first re-oxidation that was carried out isothermally at $850^{\circ} \mathrm{C}$, the second oxidation was done while heating from room temperature to $850^{\circ} \mathrm{C}$. The different oxidation conditions resulted in different oxidation kinetics, which appeared to influence the oxide growth. Upon the second oxidation, the nickel particles were seen to grow in size but did not fragment as observed during isothermal oxidation. Instead, they maintained the spherical morphology from the reduced state (cf. Fig. 4c) and the uniform growth was observed as a granulated oxide surface that developed externally around the grains (cf. Fig. 4d and e).
The sample investigated in ESEM did not display any micro- or macro-cracks after being subjected to the redox cycling.

\section{Discussion}

The conventional microscopy techniques do not provide detailed information at the single grain level. The resolution of the light microscope restricts the characterization of the nickel particles (cf. Fig. 1) and, with SEM, the microstructural changes are only qualitatively observed in the oxidized cermets (cf. Fig. 2). Heating in ESEM appears to be a valuable technique to obtain information of the structural changes at the grain level that occur during reduction and re-oxidation. However, in situ observations in ESEM are not appropriate for attaining statistically quantitative information of the structural changes since only few grains are observed during an experiment.

Redistribution of the nickel phase was observed during reduction and re-oxidation. The reduction in ESEM was carried out while heating. Reduction is believed to start around $300{ }^{\circ} \mathrm{C} .{ }^{21}$ Rounding of the nickel grains was seen to proceed simultaneously with reduction. The rounding was observed to proceed faster in smaller grains and with the number of redox cycles.

The re-oxidation procedure varied between the first and second cycle and the difference appeared to influence on the resulting microstructure. The first oxidation was carried out isothermally at $850^{\circ} \mathrm{C}$, where the oxidation will occur rapidly, whereas the second oxidation proceeded while heating from room temperature. In the latter case, the oxidation probably started at ca. $300^{\circ} \mathrm{C}$ and progressed slowly until $450-550^{\circ} \mathrm{C}$, at which point it increased. ${ }^{21}$ Dif- 
ferent oxide growth behavior was seen in the two cases. For the fast oxidation at $850^{\circ} \mathrm{C}$, the nickel grains divided into $2-4$ grains and growth took place by expansion of the particles into the surrounding voids. For the second oxidation procedure, a surface layer of protective nickel oxide was seen to develop around the individual nickel particles as the oxidation progressed. In both cases, the growth of the nickel phase was not observed to influence the YSZ phase that appeared microstructurally stable through all steps.

The different oxide growth behavior was observed in two successive re-oxidation steps. The preceding period of reducing conditions varied between the two cycles (respectively 44 and 141 min, cf. Table I), as did the period of oxidizing conditions (65 and 86 min, cf. Table I). Thus, the number of the redox cycle, the history of the sample, or different degrees of re-oxidation may be parameters affecting the growth pattern. However, the temperature for the initiation of the reaction is believed to be the most significant difference between the two cycles and, therefore, the temperature seems to be a dominating factor for the oxide growth.

The microstructural observations upon redox cycling made with ESEM are consistent with the model of the redox mechanism proposed in a previous paper. ${ }^{9}$ Redistribution of the nickel phase during the reducing period was found to prevent reversion to the as-sintered structure when re-oxidized. In accordance with the model, redistribution of the nickel phase in the reduced state was visibly verified by the observations during the in situ experiment. Furthermore, the ESEM investigation showed that redistribution of the nickel phase also occurred upon re-oxidation.

The model also predicted that the microstructural changes in the nickel network would lead to stresses and local failures in the t-YSZ network upon re-oxidation. The cumulative damage within the t-YSZ phase would result in bulk expansion, increased porosity, and fracture. ${ }^{9}$ When comparing the SEMs of the as-sintered and reoxidized states, increased porosity was indeed observed for the reoxidized states (cf. Fig. 2), and macro cracks were seen in the reoxidized samples.

However, no fractures were observed in the ESEM experiment. This is believed to be due to the nature of the experimental test set-up. The in situ experiment was performed on polished or fractured surfaces, where voids existed around the growing $\mathrm{NiO}$ particles, which were kept under observation. The $\mathrm{NiO}$ particles were observed to grow out of the polished surface and this was believed to prevent damage to the YSZ network of the sample.

Previous investigations have also indicated that changes in the microstructure depend on the temperature at which oxidation occurs. ${ }^{9}$ In agreement with these observations, the oxide growth, observed in the present experiment, was shown to depend on the temperature of the oxidation. The oxide growth and associated bulk expansion is a critical issue for solid oxide fuel cell operation, since the resulting mechanical stresses may generate cracks in the electrolyte. ${ }^{9}$ The oxidation temperature and the oxide growth kinetics may be parameters of interest for future development of redox stable SOFCs.

\section{Conclusions}

The microstructure of the anode cermet was investigated during different redox cycling steps. ESEM technology makes it possible to study materials at high temperature in various atmospheres. Using this technique, it was possible to follow changes in the morphology of individual nickel/nickel oxide grains in situ during reactions up to $850^{\circ} \mathrm{C}$. The reduction of $\mathrm{NiO}$ was associated with increased porosity and shrinkage and rounding of the nickel particles. The rounding occurred faster in smaller grains compared to larger grains. Reoxidation was also observed to be associated with a redistribution of the $\mathrm{NiO}$ phase. The morphology of the oxide particles was found to depend on the reaction temperature. This indicates that the redistribution process is affected by oxidation kinetics. During rapid oxidation, the NiO particles divided into $2-4$ particles, which grew into the surrounding void. For slower oxidation a surface layer of oxide grew around the nickel particles.

\section{Acknowledgment}

This work was supported by the Danish Industrial Ph.D. program. B. Davidsen and S. Ullmann (Haldor Topsøe A/S) are acknowledged for technical support with, respectively, the SEM and ESEM experiments.

Ris

Risф National Laboratory assisted in meeting the publication costs of this References

1. D. Simwonis, F. Tietz, and D. Stöver, Solid State Ionics, 132, 241 (2000)

2. R. J. Aaberg, R. Tunold, F. W. Poulsen, and N. Bonanos, in 2nd European SOFC Forum, European Fuel Cell Forum, p. 363 (1996)

3. D. Skarmoutsos, P. Nikolopoulos, F. Tietz, and I. C. Vinke, Solid State Ionics, 170 153 (2004).

4. A. Tsoga, P. Nikolopoulos, A. Kontogeorgakos, F. Tietz, and A. Naoumides, in SOFC V, U. Stimming, S. C. Singhal, H. Tagawa, and W. Lehnert, Editors, PV 97-40, p. 823, The Electrochemical Society Proceedings Series, Pennington, NJ (1997)

5. D. Fouquet, A. C. Müller, A. Weber, and E. Ivers-Tiffée, Ionics, 9, 103 (2003).

6. G. Robert, A. Kaiser, and E. Batawi, in 6th European SOFC Forum, European Fuel Cell Forum, p. 193 (2004)

7. M. Cassidy, G. Lindsay, and K. Kendall, J. Power Sources, 61, 189 (1996)

8. D. Waldbillig, A. Wood, and D. G. Ivey, in SOFC IX, S. C. Singhal and J. Mizusaki, Editors, PV 2005-07, p. 1244, The Electrochemical Society Proceedings Series, Pennington, NJ (2005).

9. T. Klemens $\emptyset$, C. Chung, P. H. Larsen, and M. Mogensen, J. Electrochem. Soc., 152, A2186 (2005)

10. D.-S. Lee, J.-W. Heo, J.-H. Lee, J. K. H. W. Lee, S.-W. Kim, G.-H. Kim, and H. S. Song, in Solid State Ionics: Trends in the New Millennium, B. V. R. Chowdari, Editor, p. 477, World Scientific Publishing Co, River Edge, NJ (2002).

11. N. M. Tikekar, T. J. Armstrong, and A. V. Virkar, in Solid State Ionic Devices III, E. D. Wachsman, K. Swider-Lyons, M. F. Carolan, F. H. Garzon, M. Liu, and J. R. Stetter, Editors, PV 2002-26, p. 81, The Electrochemical Society, Inc., Pennington, NJ (2002).

12. R. Vassen, D. Simwonis, and D. Stöver, J. Mater. Sci., 36, 147 (2001)

13. J.-H. Lee, H. Moon, H.-W. Lee, J. Kim, J.-D. Kim, and K.-H. Yoon, Solid State Ionics, 148, 15 (2002).

14. J.-H. Lee, J.-W. Heo, D.-S. Lee, J. Kim, G.-H. Kim, H.-W. Lee, H. S. Song, and J.-H. Moon, Solid State Ionics, 158, 225 (2002).

15. K.-R. Lee, S. H. Choi, J. Kim, H.-W. Lee, and J.-H. Lee, J. Power Sources, 140 226 (2005)

16. G. Stathis, D. Simwonis, F. Tietz, A. Moropoulou, and A. Naoumides, J. Mater Res., 17, 951 (2002).

17. N. M. Tikekar, T. J. Armstrong, and A. V. Virkar, in SOFC VIII, S. C. Singhal an M. Dokiya, Editors, PV 2003-07, p. 670, The Electrochemical Society Proceeding Series, Pennington, NJ (2003).

18. J. Malzbender, R. W. Steinbrech, and L. Singheiser, in SOFC VIII, S. C. Singhal and M. Dokiya, Editors, PV 2003-07, p. 1463, The Electrochemical Society Proceedings Series, Pennington, NJ (2003).

19. T. Werber, Solid State Ionics, 42, 205 (1990).

20. CRC Handbook of Chemistry and Physics, 68th ed., CRC Press, Boca Raton, FL (1988).

21. D. Waldbillig, A. Wood, and D. G. Ivey, Solid State Ionics, 176, 847 (2005). 